\title{
Role of Corporate Social Responsibility in Organization
}

\author{
Ms Yogita Sharma \\ (MBA Department, ICL Group of Colleges, Kurukshetra University, India)
}

\begin{abstract}
Corporate social responsibility is emerging as a new field in the management research. It encompasses not only what companies do with their profits, but also how they make them. It is not just for large scale companies but also used by small scale and non-profit organizations. In India many firms have taken the initiatives of CSR practices which have met with different needs of the society as a whole. Data has been collected from number of articles, books, periodicals and websites. The present study has been an attempt to generate awareness and to understand meaning, significance, dimensional aspect of CSR and how to manage it. An extensive literature review is done on CSR. At the end some forces at work, some issues related to CSR in India and some recommendations are given.
\end{abstract}

Keywords: Meaning of CSR, Significance, Social aspect, Economic aspect, Environmental aspect, Managing CSR, Forces at work.

\section{Introduction}

Corporate social responsibility (CSR) is a prominent 21 st century business ideology that heightens expectations of companies regarding social and environmental standards. The results of CSR compliance are generally viewed as a good thing by most companies. The main question arise before studied about CSR is Why do businesses exist? The answer may be to earn profit. But if we go deeper and try to get real reasons, we come to the conclusion that in a company a groupof people get together so that they are able to accomplish something collectively that theycould not get separately and they contribute to the society. Challenges lie in allocating time and resources necessary to develop a CSR approach that meets governmental and social standards and achieves compliance with informal CSR guidelines related to social and environmental responsibility. One of the biggest features addressed by CSR is its intent to cause companies to recognize responsibilities to stakeholders outside of shareholders. This includes customers, communities, employees and suppliers. While proponents of CSR point out the long-term benefits of taking care of these core relationships, shareholders are often deterred at the notion that companies will invest in anything that does not create immediately obvious financial gain. With CSR, detecting measurable bottom line benefits is a challenge as social and environmental programs are hard to account for with regard to financial gain.

The evolution of corporate social responsibility in India refers to changes over time in India of the cultural norms of corporations' engagement of corporate social responsibility (CSR), with CSR referring to way that businesses are managed to bring about an overall positive impact onthe communities, cultures, societies and environments in which they operate. The fundamentals of CSR rest on the fact that not only public policy but even corporates should be responsible enough to address social issues. Thus companies should deal with the challenges and issues looked after to a certain extent by the states.

Among other countries India has one of the richest traditions of CSR. Much has been done in recent years to make Indian Entrepreneurs aware of social responsibility as an important segment of their business activity but CSR in India has yet to receive widespread recognition. If this goal has to be realized then the CSR approach of corporate has to be in line with their attitudes towards mainstream business- companies setting clear objectives, undertaking potential investments, measuring and reporting performance publicly.

\section{Literature Review}

Blowfield, M. (2005) found a critical approach to CSR not only requires us to ask how CSR affects company behavior in developing countries, but also to ask if, and how, business is affecting the meaning of development itself. The author argues in this article that business is indeed affecting development, and one of the ways this happens is by allowing business thinking to dominate the way we view the world and to become the norm against which everything else is tested for true and false value.

Chaudhary and Wang (2007) found that the number of companies with disclosures on internet isnoticeably low in India in top 100 Information Technology companies. Though the study did notattest the lack of CSR activities but it certainly attested lack of proactive CSR communication, simplyput the companies carried out CSR activities but did not disclose them properly. 
Hossain and Reaz (2007) investigated the extent of voluntary disclosures by 38 listed bankingcompanies in India. The empirical research concluded that the size and assets were the significantfactors influencing disclosure whereas age, diversification, board composition and multiple exchangelisting and complexity of business are not significant variables influencing social reporting practicesof Indian banking companies.

Murthy (2008) examined the corporate social disclosure practices of the top 16 software firms inIndia. The 2003-2004 annual reports were analyzed using content analysis and it was found that thehuman resources was the most frequently reported followed by community development activitiesand the environmental activities was the least reported. Most of the information was qualitative andwas disclosed in the 'other' sections of the annual report. Some firms had separate sections for eachcategory while many others disclosed their social practices in the introductory pages of the annualreport. The researcher suggested that shortage of skilled labor in the software sector might have leadto social disclosure (CSD) practices in the human resources. Firms seemed to have engaged incommunity development activities without expecting changes to their economic performance and theCSD of community activities seemed to be shaped by the expectations of the society.

Jatana and Crowther (2008) edited book named "Corporate social responsibility - theory and practicewith case studies" has shed light on myths of Corporate social responsibility, value addition,

Globalization perspectives on corporategovernance whistle blowing policies as corporate socialresponsibility and other contemporary issues in corporate social responsibility. In addition, it dealtwith various case studies related to various industrial sectors insurance, private banking, SMEs, Information Technology, power generation sectors and companies like Abuja cements, Coca- Cola.In all these articles details of current projects pursed by companies has given but the CSRD has notbeen measured as such.

Plankenet al (2010) investigated CSR platforms and the communication surrounding those platformsin India and established that the CSR platforms are typically used, together with stakeholder attitudesto both the form and content of those platforms. The authors presented the fact that the selected Indiancorporations pursued a primarily philanthropic platform with a focus on community developmentprojects, as predicted by previous studies. It also indicated, however, that Indian consumers may notvalue philanthropic CSR as highly as other CSR initiatives.

\section{Methodology}

The prepared paper is a descriptive study in nature. The secondary data and informationhave been analyzed for preparing the paper extensively. The secondary information havebeen collected from different scholars' and researchers' published books, articlespublished in different journals, periodicals, conference paper, working paper and websites.

\section{Dimensions of CSR}

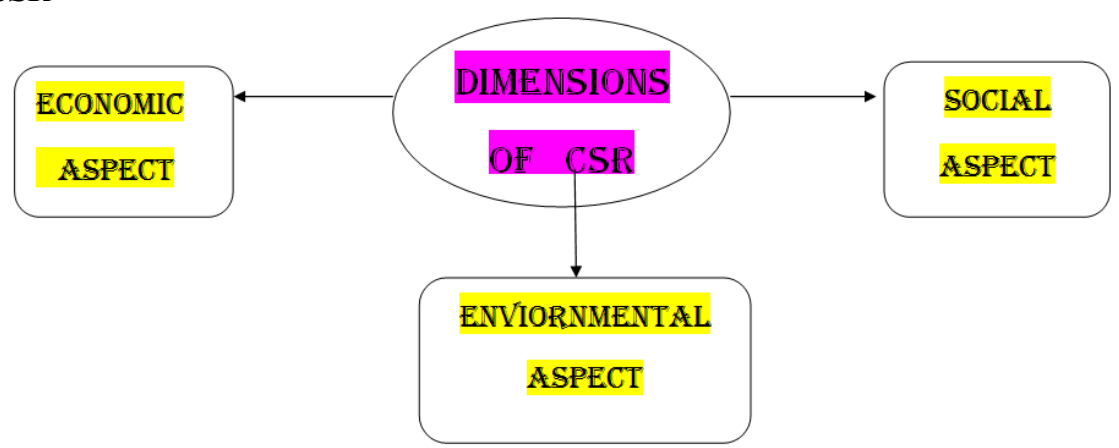

The three dimensional aspect of corporate social responsibility (CSR) includes :-

$\checkmark$ Economic aspects.

$\checkmark$ Social aspects.

$\checkmark$ Environmental aspects.

\section{Economic aspects of CSR}

The economic aspects of CSR consist of understanding the economic impacts of thecompany's operations. The economic aspects of CSR is often mistakenly considered to be synonymous withfinancial issues, which is why it has been assumed easier to implement than the other twopillars of the temple. However, the economic responsibility is not simply a matter ofcompanies being financially accountable, recording employment figures and debts intheir latest corporate responsibility report. The economic dimension of the 
sustainabilityagenda should rather consider the direct and indirect economic impacts that theorganization's operations have on the surrounding community and on the company'sstakeholders. That is what makes up corporate economic responsibility.

\section{a) Effect on Stakeholders}

The economic performance of a company has direct and indirect impacts on all of itsstakeholders including its employees, local governments, non-profit organizations,customers, suppliers, and the communities in which the companies operates. A good economic performance makes it possible to develop operations for the long term and to invest in development and the well-being of employees. The employees of the company get good salaries, from which they purchase goods and services as well as pay taxes. These activities fuel the local service industry, government programs and the community activities. This multiplier effect becomes all the more important if thecompany is one of the largest employers in the communities.

\section{b) Through taxes}

Companies are major contributors to the well-being of the area surrounding theiroperations, for example through the local tax base. Therefore, the question arises: is itresponsible for a business to see corporate taxes purely as to cost be avoided, rather thanpart of their social contract with society? Taxes have a significant impact on the creationand distribution of wealth: tax avoidance, though perfectly legal, deprives the communityin the area of the company's operation of well-being.

\section{c) Maintaining Trust}

A company's license to operate depends upon the trust and support of the localcommunities where it operates. The shift in power from the public the private sectoremphasizes the importance of this trust - and the obligations and responsibilities thatcome with it. Some company activities are potentially very destructive to the trust earnedfrom the community or otherwise cannot be regarded as economically responsible. Theseshould be avoided or at least carefully considered. Example of such harmful companybehavior include: bribery and corruption, tax avoidance: and concentration of rewardsand incentives of the company's performance to few individuals only instead of fairerdistribution among the personnel. The company should also stop to consider theeconomic effects of changes in locations and/or operations to the community.

\section{Social Aspects of CSR}

Social responsibility is the newest of the three dimensions of corporate socialresponsibility and it is getting more attention than it has previously had. Manyorganizations are becoming increasingly active in addressing social concerns socialresponsibility means being accountable for the social effects the company has on people -even indirectly. This includes the people within the company, in the supply chain of thecompany, in the community the company is in and as customers of the company whichmeans the whole lot of stakeholder. It refers to the management's obligation to makechoices and take actions that will contribute to the well fare and interests of society aswell as those of the organization. The following aspects have been found to be key thesocial aspects of CSR for an organization.

\section{a) Responsibility of CSR towards Customers}

The idea of treating customers with respect and attention is not new to business: oftenbeing responsible to customers has a direct positive effect on the company's profits. There are, however, broader social responsibilities including providing good value formoney. These responsibilities may include such issues as the safety and durability ofproducts or services; standard or after sales service; prompt and courteous attention toqueries and complaints; adequate supply of products or services; fair standards ofadvertising and trading; and full and unambiguous information to potential customers.

\section{b) Responsibilityof CSR towards Employees}

Businesses are major contributors to the employment generation of the community.However, social responsibility to employees extends beyond terms and conditions of theformal contract of employment. Companies need to come up with wider expectations thattoday's employees have for the quality of their working life. Such expectations includetaking care of the personnel's welfare and safety at work and upholding their skills andmotivation for the work. Beyond these expectations, a socially responsible companysecures a just treatment and equal opportunities for all its employees, regardless ofgender, age, race, or religion.

\section{c) Responsibility of CSR towards the Community}

Companies depend on the health, stability, and prosperity of the communities in whichthey operate. Often majority of the company's employees and customers come from thesurroundings area - especially so for 
SME's. The reputation of a company at it s location, its image as an employer and producer, but also as an actor in the local scene, certainlyinfluences its competitiveness. Many companies become involved in community causes,for example by providing additional vocational training places, recruiting sociallyexcluded people, sponsoring local sports and cultural events, and through partnershipswith communities or donations to charitable activities.

\section{Environmental aspects of CSR}

Environmental concern and sustainable development is a key pillar of the corporate socialresponsibility. Environmental and ecological issues have been an important topic ofdiscussion for the past thirty years in the business world - the longest time of the threedimensions corporate social responsibility. The knowledge and issues within thedimensions have progressed across a landscape of changing business realities.Environmental aspects put in place in the 1970s with the first real understanding of theenvironmental impacts of business.

\section{a) Environmental Impact}

Corporate activity may have many types of effect $\mathrm{s}$ on the environment. Usuallyenvironmental impact refers to the negative effects occurring in the surrounding naturalenvironmental due to business operations. Such impacts may include: overuse of natural,non-renewable resources of energy, pollution wastage, degeneration of biodiversity,climate change, deforestation etc. Since many business - related environmental problemtranscend national boundaries, most companies $\mathrm{s}$ are thus actors in global environment.

\section{b) Measuring Environmental Impact}

Environmental impacts can be measured in severalways through environmentally extended inputoutput tables, material input per serviceunit (MIPS) calculations, ecological footprint and life cycle assessment, to name a few.Ecological footprint measures the amount of nature's resources consumed in a givenyear, and compares it to the resources available in the world. Life cycle assessment (LCAor eco-balance) is used to assess the environmental performance of a product from rawmaterials in the beginning of the production process all the way to disposal at the end ofuse. The MIPS value is calculated by dividing the amount of material the product orservice causes to movee.g. the amount of earth moved in mining, not just the metalused - during its entire life - span by the amount of benefits and value its brings.

\section{c) Environmental Management}

To truly commit to its environmental responsibilities acompany should change its traditional modes operation towards a more environmentallyoriented one. The environmentally more responsible perspective could include suchissues as an emphasis on increased resource productivity, cleaner production and activedialogue with the company's stakeholders. Many businesses have found that establishingan environmental management system is the best basis for good environmentalperformance. Quality, health and safety issues can also be integrated into the samemanagement system.

\section{d) Environmental Responsibility}

Several individual companies have found that improving environmental performancemay also have beneficial effects on the company itself. Using less material andstreamlining processes to create less waste may lower the costs of operation significantly.Moreover, the close review of operations, which is needed to improve the environmentalperformance, may reveal other improvement points, such as risk and material loss. Aresponsible public image may also attract more customers. State governments can fulfill their role in helping business to identify marketopportunities and undertake win-win investments, the action program also set out anumber of other measures aimed at business: establishment of a compliance assistanceprogram to help business understand the environmental requirements of the EuropeanCommunity; development of national, but harmonized, company environmentalperformance reward schemes that identify and reward good performers and encouragevoluntary commitments and agreements.

\section{Significance of CSR: -}

CSR plays very significant role in smooth functioning of organizations. It includes:-

\section{a) Social Responsibility and Customer Relationships}

One of the foundational elements of CSR is that it causes companies to reason beyond basic ethics to consider the benefits of active involvement in communities. In his article "The 7 Principles of Business Integrity," business strategist Robert Moment argues that 21st-century companies must prove themselves to 
customers to build long-term, trusting relationships. They must also get involved in the community to give back. This community connection endears your company to the local markets in which you operate.

\section{b) Motivated Employees}

Employees are a company's most valued asset. This is the premise of a company's obligation to this key stakeholder group with regard to CSR compliance. This means treating employees with respect and offering fair working conditions. It also means establishing fair hiring practices and promoting a non-discriminatory workplace. This improves morale within the workplace and encourages teamwork.

\section{c) Profitability and Value}

A CSR policy improves company profitability and value. The introduction of energy efficiencies and waste recycling cuts operational costs and benefits the environment. CSR also increases company accountability and its transparency with investment analysts and the media, shareholders and local communities. This in turn enhances its reputation among investors such as mutual funds that integrate CSR into their stock selection. The result is a virtuous circle where the company's stock value increases and its access to investment capital is eased.

\section{d) Showing a True Commitment}

The most successful corporate social responsibility programs integrate these two types of CSR together to show a true commitment to a cause. For example, a company that uses sustainable materials in their products, donates financial resources to environmental causes, and allows employees to take paid time off for volunteering at environmental charities would be showing a true commitment to the environment that goes beyond any single CSR initiative.

\section{e)Social Media Visibility}

One of the reasons that corporations should have visible CSR campaigns is due to the importance and prevalence of social media. Corporations that want to protect their brand understand that social media is an integral part of public perception. When a corporation exercises social responsibility in the form of fundraising or setting up employee giving programs, using social media to promote these actions helps to create a positive branding environment and it is a great way to engage with your audience on a deeper level that goes beyond your products or services.

\section{f) Public Relations Benefits}

Public relations are a potent tool for shaping consumer perception and building a company's image. Corporations that actively promote their social responsibility activities often take steps to publicize these efforts through the media. Getting the word out about corporate donations, employee volunteer programs, or other CSR initiatives is a powerful branding tool that can build publicity for you in both online and print media.

\section{g) Government Relations}

Corporations that place an emphasis on corporate social responsibility typically have an easier experience when dealing with politicians and government regulators. In contrast, businesses that present a reckless disregard for social responsibility tend to find themselves fending off various inquiries and probes, often brought on at the insistence of public service organizations. The more positive the public perception is that a corporation takes social responsibility seriously; the less likely it is that activist groups will launch public campaigns and demand government inquiries against it.

\section{h) Building a Positive Workplace Environment}

Finally, one of the greatest benefits of promoting social responsibility in the workplace is the positive environment you build for your employees. When employees and management feel they are working for a company that has a true conscience, they will likely be more enthusiastic and engaged in their jobs. This can build a sense of community and teamwork which brings everyone together and leads to happier, more productive employees.

\section{Managing For Social Responsibility}

For managing social responsibility many steps are taken by the different companies for doing significant improvements in theirenvironmental and social management practices.

\section{Corporate Governance}

In general, governanceis about how power, privilege, and wealth are distributed and howand by whom they are exercised. In a corporate sense,governance involves defining a vision and the overall direction ofthe firm, setting standards, overseeing the allocation of financialand human resources, and balancing the interests of stakeholdersor constituencies. It is increasingly recognized that governancemust also be concerned with the sustainability of the enterpriseand the values that guide decision making and the articulation andcommunication 
of the core ideology of the firm. It is concernedwith the relationships between shareholders, management, andthe Board of Directors and increasingly with other keystakeholders or constituencies.

\section{Organizational Alignment}

Leading edge companies, those that have prospered andsurvived over time, have shown more than a clear sense ofpurpose and core values. They have also translated them intoaction and ensured that they are reflected consistently throughoutthe organization in everything the company does. They achievethis alignment through:

- Their goals, strategies, tactics, and systems,

- The way they organize (structures, building, office layouts),

- Their human resource policies and practices, and

- Their day-to-day decisions.

\section{Audits and Accounting Practices}

During the past ten years, a number of business networks andcompanies have engaged in environmental and social accounting.

Several NGOs and multi-sector partnerships such asAccountAbility and the Global Reporting Initiative havepioneered the development of standards, terminology, andaccreditation procedures for social and ethical accounting andauditing. These innovative approaches arebased on relatively sophisticated efforts to determine what isconsidered to be important for each of the stakeholders and thento define specific objectives and action programmes for priorityareas of performance improvement. The annual social reportsevaluate performance against these plans just as the annualfinancial reports show financial results compared to prior yearsand sometimes objectives.

\section{Educating for Social Responsibility}

There is reason for some optimism about the increasing recognition of the need to build business ethics, environment, andsocial responsibility into educational programmers for businessstudents and managers. Ethics and entrepreneurship are on theexecutive education agenda.

\section{Forces at Work}

Most business leaders would agree that they are managing intimes of turbulence and accelerating change. They would alsofind a consensus about most of the trends and forces which arechallenging their traditional views of competitiveness and of thesuccess factors for survival and profitability. These forcesinclude the following:

I. Globalizationof markets, consumer preferences, supply chainsand financial flows. Some business leaders considerglobalization to be a revolution, not simply a trend, since it ishaving momentous effects on the economies of all countries andon corporations in most sectors.

II. Increasing intensity of competition. Peter Veil used theexpression 'managing in white water' to express the challenge ofmeeting the turbulence and instability which global competitionhas created. It is unlikely we will ever return to the comfortable1970's.

III. Rapid technological changesare transforming markets,alleviating burdensome tasks, enabling greater customization ofproduction, and contributing to high labour displacement.

IV. Modern information technology makes it possible to decentralizedecision-making without losing control and to introduce moreflexible and less hierarchical structures.

V. A shift from an industrial economy to a knowledge andinformation based economy. Human capital is replacing financialcapital as the most important strategic resource. Traditionalconcepts of work, of jobs, and of motivation are beingchallenged.

VI. Demographic changesnot only threaten the sustainability ofour planet but create a mismatch between jobs and suitablytrainedworkers, and between present educational systems and theneeds of a knowledge and information-based economy.

VII. Environmental challengescaused by pollution and resourcedepletion test the sustainability of our planet earth. Businessleaders are called upon to play an important role in meeting thesechallenges.

VIII. Changing value systemsare finding expression in different lifestyles and expectations on the part of employees, customers, andcommunities as a whole. As the world business environment changes, so do therequirements for success andcompetitiveness. Because of theabove forces at work, building deeper 
and more strategicrelationships with customers, suppliers, employees, communitiesand other stakeholders (the corporate eco-system) can becomecentral to competitiveness and even survival.

IX. Building theserelationships can form the foundation for a new, progressiveand people-centered corporate strategy which attacks thesources - not the symptoms of challenges facing businesstoday.

\section{Current State of CSR in India}

CSR is not a new concept in India. Ever since their inception, corporate like the Tata Group, the Aditya Birla Group, and Indian Oil Corporation, to name a few have been involved in serving the community. Through donations and charity events, many other organizations have been doing their part for the society. The basic objective of CSR in these days is to maximize the company's overall impact on the society and stakeholders. CSR policies, practices and programs are being comprehensively integrated by an increasing number of companies throughout their business operations and processes. A growing number of corporate feel that CSR is not just another form of indirect expense but is important for protecting the goodwill and reputation, defending attacks and increasing business competitiveness.

Companies have specialized CSR teams that formulate policies, strategies and goals for their CSR programs and set aside budgets to fund them. These programs are often determined by social philosophy which have clear objectives and are well defined and are aligned with the mainstream business. The programs are put into practice by the employees who are crucial to this process. CSR programs ranges from community development to development in education, environment and healthcare etc.

For example, a more comprehensive method of development is adopted by some corporations such as Bharat Petroleum Corporation Limited, Maruti Suzuki India Limitedand Hindustan Unilever Limited. Provision of improved medical and sanitation facilities, building schools and houses, and empowering the villagers and in process making them more self-reliant by providing vocational training and a knowledge of business operations are the facilities that these corporations focus on. Many of the companies are helping other peoples by providing them good standard of living.

On the other hand, the CSR programs of corporations like GlaxoSmithKline Pharmaceuticals' focus on the health aspect of the community. They set up health camps in tribal villages which offer medical check-ups and treatment and undertake health awareness programs. Some of the non-profit organizations which carry out health and education programs in backward areas are to a certain extent funded by such corporations.

Also Corporate increasingly join hands with Non-governmental organizations (NGOs) and use their expertise in devising programs which address wider social problems.

For example, a lot of work is being undertaken to rebuild the lives of the tsunami affected victims. This is exclusively undertaken by SAP India in partnership with Hope Foundation, an NGO that focuses mainly on bringing about improvement in the lives of the poor and needy. The SAP Labs Center of HOPE in Bangalore was started by this venture which looks after the food, clothing, shelter and medical care of street children.

CSR has gone through many phases in India. The ability to make a significant difference in the society and improve the overall quality of life has clearly been proven by the corporate. Not one but all corporate should try and bring about a change in the current social situation in India in order to have an effective and lasting solution to the social woes. Partnerships between companies, NGOs and the government should be facilitated so that a combination of their skills such as expertise, strategic thinking, manpower and money to initiate extensive social change will put the socio-economic development of India on a fast track.

\section{Conclusion}

The evolution of corporate social responsibility in India refers to changes over time in India of the cultural norms of corporations engagement of corporate social responsibility (CSR), with CSR referring to way that businesses are managed to bring about an overall positive impact on the communities, cultures, societies and environments in which they operate. The fundamentals of CSR rest on the fact that not only public policy but even corporate should be responsible enough to address social issues. There are three dimensional aspect of corporate social responsibility (CSR) includes Economic aspects, Social aspects, and Environmental aspects. How social responsibility is significant for organizations like by motivating employees, profitability, increasing value etc. For managing social responsibility many steps are taken by the different companies for doing significant improvements in their environmental and social management practices. Different forces at work which help in managing CSR which includes globalization, technological, environmental changes etc. At the endcurrent State of CSR in India. Different Indian companies used CSR. Companies have specialized CSR teams that formulate policies, strategies and goals for their CSR programs and set aside budgets to fund them. These programs are often determined by social philosophy which have clear objectives and are well defined and are aligned with the mainstream business. The programs are put into practice by the employees who are crucial to this process. CSR programs ranges from community development to development in education, environment 
and healthcare etc. CSR contributes a lot to the organization. Every organization should adopt it make their business more efficient and profitable.

\section{References}

[1] Blowfield, M. (2005). Corporate social responsibility: Reinventing the meaning of development. International Affairs, 81, 515-524

[2] Chaudhri, V., \& Wang, J. (2007). Communicating corporate social responsibility on the Internet: A case study of the top 100 IT companies in India. Management Communication Quarterly, 21, 232-247.

[3] Mohammed Hossain and MasrurReaz, "Corporate Social Responsibility and Environmental Management”, Volume 14, Issue 5, pages 274-288, December 2007

[4] Murthy, V. and Abeysekera, I., Corporate social reporting practices of top Indian software firms,Australasian Accounting Business and Finance Journal, 2(1), 2008.

[5] RenuJatana, David Crowther, (2007) "Corporate Social Responsibility and the Empowerment of Women: An Indian Perspective", Social Responsibility Journal, Vol. 3 Iss: 4, pp.40 - 48 